DOI: $10.15643 /$ libartrus-2016.5.4

\title{
Configurations of reading as a constitutive aspect of consciousness
}

\author{
(C) A. V. Shutaleva1*, E. A. Putilova ${ }^{2}$ \\ 1 Ural Federal University \\ 51 Lenin Ave., 620000 Ekaterinburg, Russia. \\ ${ }^{2}$ Nizhni Tagil Technological Institute (branch of Ural State Technical University) \\ 59 Krasnogvardeiskaya St., 622000 Nizhny Tagil, Russia. \\ *Email: ashutaleva@yandex.ru
}

\begin{abstract}
The article is devoted to analysis of the constitutive aspect of consciousness that manifests in the eventfulness of mind and the reality constituted by it, presented as a textual reality. Appeal to the understanding of space and text makes it possible to view the reading space as a metaphorical "twofold" space, which is constituted by intersection and superposition of "places" that, in their state of becoming, suggest the perception of reality that is set by the possibility of infinite textual interpretations. The authors examine whether it is conceivable that there be evoking configurations of reading allows to represent the problem of consciousness in the context of finding something that ontologically roots consciousness in the world, suggests its constitutive, subjectivity-forming aspect that manifests in the eventfulness of consciousness and the reality constituted by it. Invoking mystical tradition allows us to consider text as a "place" with singular internal tension line where coexistence produces not an abstract, but individual and qualitatively diverse space. In the mystical tradition Beeng questioning as that which exists before things and is their foundation but is not something partial to existence. In this regard, the text defined as a reality, which implies concealment and remains something intimate, impossible to control completely. In connection with this symbol is seen not only as a linguistic phenomenon. Configurations of reading are considered an entity where can be foundation, creation and procreation of meanings and interpretations.
\end{abstract}

Keywords: event, reading, consciousness, mystical experience, interpretation.

\section{Introduction}

Modern philosophy tends to focus not on the ways a reality can exist, but on the ways it can be shaped and defined. As E. V. Bakeeva poignantly notes, "ontologization of language and shaping of non-substantial (eventful) ontology themselves, in turn, become manifests of event that can be defined as ultimate proof of consciousness' totality" [1, p. 9]. A figure of reading that assumes the attentive gaze, co-existence of several centers of attraction which concentrate not only positive aspects of reality, but also that assume evocation of cataphatic descriptive tradition [31-33]. A number of key issues arise from the statement. For instance, in the teachings of Dionysius the Areopagite God transcends the world, existing both outside and inside simultaneously: "He is the cause of all being, but $\mathrm{He}$ is also not any part of being, because he transcends everything natural and supernatural... He transcends any negation and any affirmation" [6, p.6].

To say is to show, to proclaim, make visible and audible: "And God said: 'Let there be...' To say is to pull from being into existence" [13]. But language is not only an explanation aspect of being. Being, to use the words of M. Heidegger, is a refusal of such explanation, it is something non-explanatory, it is abyss, something "that represents the present" [12, p. 380]. Being is anticipatory, it is Nothing, it 
exists before things and is their foundation but is not something partial to existence. Perhaps to correlate with modern scientific theories, which represent research of "soul gene expression in metazoan development, and provides the basis to understand the genetics of tetrapyrrole metabolism in a wide range of embryonic processes" [7, p. 360]. Genes are the text, which is embodied in a living body. Nothing, gaining its essence through Word, becomes "something". It is also logical that "the very necessity to 'give unto' and 'belong' to language in this figure of hearing and listening casts doubt on the autonomous existence of the one who performs all these actions" [1, p. 7].

For the entire Christian tradition the world as well the book, stands for the unity of symbols: things and words have meaning beyond themselves; they also stand for something else, signifying the signified being behind them. God creates the world through Word that human being bear inside them. Because this should be of particular interest is the question of mystical tradition and mystical explanations. Mystical tradition associated with an experience of religious ecstasies and all that is related to ecstasy, that is, ideologies, ethics, rites, myths, legends, magics [29]. Description of mystical ecstasy is associated with the religious tradition in which people brought. Christianity has a developed education system, which allows the educational process for all human life $[3,4,11]$.

According to some experts the problem of mystical explanations related to the question of esoteric knowledge. For example, L. Scott expresses the following idea: "it is conjectured by Jewish scholars that sections of the Book of Exodus and the Book of Ezekiel contain word sounds that are used in these advanced transcendental techniques that are employed to avert dangers yet to come. Finally, the supernormal abilities, reflective of mental and physical purification, which come naturally through the practice of transcendental techniques, are seen to be used by the Patriarchs and Prophets throughout the Old Testament to help the Jewish nation and individual Jewish people when they were in need" [41, p. 273].

"In the beginning was the Word, and the Word was with God, and the Word was God....Through him all things were made..." [John 1:1, 1:3]. The uttering is the superposition of non-locality "places" that belong both to existence and to the being-as-Nothing that, in presence, allows one to reach its essence, be fulfilled in its own existence [34].

\section{Discussions}

All Christian symbolism is rooted in words - to name a thing means to explain it, gain insight into its nature, since the being of a name is revealed in its own energies and only in them [26, p. 108; 24]. One of the most striking features of this problem is that this energy operates in "another", revealing to us its "out-side", its intimate and unexpressionable, it is possible only due to the apothetic aspect in subjective being of name and word. That is why any symbol is possible as a linguistic phenomenon, as something through which consciousness knows another as well as itself, hence name is magical. The nature of name is magical due to the name itself becoming mythical/magical word through which entity is completely submerged in another [9]. The human being takes in the world being in a ritualized symbolic action $[14,18,25]$. Therefore, fairly represent the view that "Several rituals were invented to prevent more misery, and certain experts thereby gained considerable importance. The various ways in which people shaped, interpreted and negotiated the meaning of the disaster are interconnected with their understanding of tradition and modernity" [40, p. 112]. The symbol has a special semantics $[16,20]$.

One should, nevertheless, consider the problem of the symbolic knowledge in understanding symbol as a architectural phenomenon. According to some experts "The content of a symbol is always 
perceived as a sort of abstraction 'slipping from comprehension nets' by symbolism supporters. A creative intuition only allows approaching to comprehension of symbols but it can never exhaust its sense. Semantic interpretation of a symbol always takes a symbolic form and for this reason turns into 'dark infinity'" [10, p. 827]. This statement suggests that world, people, words and things are the image of God, but also His manifestations. The invisible of God is visible through His creation. And it is to the man created from earthen ashes that the God granted the right to name all living things, the pre-man and creation from matter, to man made of flesh and blood. And language as His gift is a way of co-being of man and God, a melody of materialization and co-materialization. In this respect, we follow the definition of M. Heidegger language as being home in which thought gives Word to being. In this regard, we agree with the opinion that despite the notion of ineffability of mystical experience, "people can meaningfully communicate their mystical experiences, and that quantitative language analyses provide a means for understanding aspects of such experiences" [51, p. 244].

A textual message is meant for everyone, but to see only one meaning in it is to see nothing, since the text gains corporeality formed by partition of letters, signs, bends and labels in its texture and folds, rotations and transfusions of meanings in the locality of event, that allow us to describe its spatial characteristics. We find particularly insightful the point of view presented by T. V. Itzkovich who writes: "Textual space (locality) is a property inherent to all objects of reality; this is the reason why spatial characteristics are given even to those objects that are not spatial by nature (e.g., concepts and conceptions)" [15, p. 113]. Textual space creates reality as a models of human been. In the mystical tradition it is models of subjectively believe: "Mystical experiences, or subjectively believed encounters with a supernatural world, are widely reported across cultures and throughout human history" [5, p. 112]. In this aspect, we close understanding of the model proposed by Steven D. Katz, who understands a model not as a theoretical design, "but rather the nature of 'individuals' who become norms for their tradition in a variety of ways" [19, p. 247]. Mystical knowledge involves intuition as one of the most preferred ways of learning: "Intuition may be defined as understanding or knowing without conscious recourse to thought, observation or reason. Some see this unmediated process as somehow mystical while others describe intuition as being a response to unconscious cues or implicitly apprehended prior learning" [8, p. 683].

The infinite ambiguity of the Holy Scripture allows everyone to discover their own meanings, since encounters with the text create coexistence in space that is understood in a singular way: it is not abstract and homogenous, but individual and qualitatively heterogeneous. Omissions, ellipses and elisions in biblical writs of Experience (authored by Moses, Abraham, John and others) are signs of happening co-being, for mystical journey is a journey happening "in a single place". This "empty space" is where meaning is, for "emptiness is the perfect neutral space that anticipates any signs of God appearing" [37, p. 61]. In mystical journey change of place means change in state of traveler himself, with a singular, introversive line of tension that defines signs and marks of the world [30, 33, 45, 49]. Being "the Revelation of Jesus Christ that was given to him by God to show His servants what is to come", the Book of Revelation was written by John the Apostle "in a spirit"; that is why it references the reality on the other side of the living word and emerges as a "transition" that has no smoothness so inherent to the natural space, for it is a "jagged curve of act of faith" (in the words of Valeriy Podoroga). Friedrich Nietzsche, having refused the meaning of Jesus's teachings, instead examines the life of Jesus, actualizing his "innermost" concepts of life, truth and light [35, p. 662]. For Nietzsche, anything beyond his life experience is unknown; while believing in life, in the becoming he nevertheless denies the man who became. As T. S. Kuzubova notes, "In the metaphysical world of Nietzsche the 
phenomenon of Christ is a symbol of eternity present in the moment, the embodied possibility of conception of meaning in the purposeless stream of becoming" [23, p. 186]. Nietzsche in his work "Human, All Too Human" calls Jesus the noblest man, but he considers this portrayal an antithesis to the image of Christ that was historically adopted by traditional Christianity in an attempt "to make man feel sinful” [36, p. 321].

The image of Jesus as presented by Nietzsche is "antimetaphysical", because Jesus "lives in truth" that does not distinguish between the real and the false world, accepting the undivided reality. For Nietzsche, Jesus is the cause for erasing the distinctions between God and human, for he is capable, through unlocking the limitless depth in himself that defines his "potential absoluteness", to demonstrate the actual absoluteness of a concrete man who destroys $\sin$ as a distance between God and human. In this interpretation sin becomes the inner state of individual. "The Kingdom of God" is described by Nietzsche as "experienced by heart; it is everywhere and nowhere" [35, p. 664]. But despite his affinity for ideas of Jesus, Nietzsche struggled "to break the will for nothingness", to overcome himself, to create the notion of superhuman, "saying yes to life". Through his philosophy he fights "the historical disease" that "paralyses life, bereaves it of spontaneousness"; unless history is counterbalanced by "flexible giftedness and creative straightforwardness", it becomes "deadly", it becomes "death itself" [27, pp. 362-363].

Despite the pathos inherent in the works of Nietzsche and their various interpretations, Podoroga correctly identifies Nietzsche's writings as an attempt to transfer to another a new bodily experience, Dionysian in its essence, that pushes another from static states of consciousness into the realm of ecstatic experiences, revelations of oneself "in the long journey beyond the boundaries of ennui of idempotence", with an attempt to "form one's own body in the experience of other bodily practices" [38]. The eventful nature of insight serves as a foundation of self-ecstatic revelation of subjectivity [46], where $\mathrm{Me}$ and another become possible, because we are visible, distinct. The assumption of another and the body of another allow to draw one's own boundaries and then transcend them, because $M e$ and another are not objects, but centers of agency and action [47]. Thus, in Christian mystical experience the moment of unity between man and The Creature of God through the Marriage of God that is understood as "something not only spiritual but also carnal, for what is it if not the greatest manifestation of human Self, and Self is the man with flesh and spirit" [28, p. 59]. In this unity the soul gains " great force": in the moment of ecstasy, of being possessed by God the body can be lifted into the air; one gains the ability to see Jesus and hear Him. Katoche, the Ancient Greek word for possession, was also the synonym of ecstasy in Dionysian sacraments. For instance, the death of Saint Teresa of Ávila "was nothing else but exultation of love so intense that my body could not bear it..." [28, p. 188], as she will tell to one of the monks, appearing to him after death. St Teresa's mystical experience shows that women's perception of the divine should be described in positive terms, that is contrary to the traditional conception of the hysterical and anxiety symptoms [17, 52]. In this regard, of particular interest is the work of Colleen Ward, which describes that the women's spirit possession regarded as a symptom of personal maladjustment and as a form of social protest based on psychosocial, role-related pressures [50, p. 411].

The act of being itself becomes possible only in love for God, for "when you finally give in to it completely, you shall, by your own will, begin to mortify yourself and it will start to become your life. It will not kill you but will create you to live only its life and then you shall live not by your own but its will, for your will shall become its will; thus you will be dead to yourself and alive to God" [2. p. 106]. It is his own life that Job was willing to sacrifice in the name of faith. The God described by Lev Shestov 
is the God of Job: always "present" and "hidden", with no knowledge of "where He is going" [42, p. 409]. According to Shestov, the path of Job is the dialectics of humanity itself. Job suffered "terrible grievances", but, having remembered "the true freedom of the man of paradise", he "loses all fear and awakes to daring"; being "the best man of all-being" he has not "smothered in himself... the pathos of freedom" and managed to achieve the state of "living man" [21, p. 70]. The image of Job correlates with the "underground man" described by Shestov, since he opposed the wisdom of the world with his "madness" and did it as "equal to equal": "It is necessary to live without confidence, without assurance. It is necessary to give one's own spirit into hands of another, to become a material of sorts, to become clay from which invisible and unknown potter will shape something that is also completely unknown... He does not "think", he dashes to and fro, knocks at every door, bumps into every [wall]. He does not guide himself any more, he is possessed by the force that is infinitely more powerful than himself" [43, p. 61]. This is a call to sacrifice everything, even "eternal" truths, to find God. Shestov, having refused the truths and values of real life, was unable to find another solid foundation besides "solitude before God and a completely unfounded belief in the saving grace of absurdity" [22, p. 224].

\section{Conclusion}

On the whole, the text is considered an independent entity that can be disposed or opposed to revealing itself. Reading of the text is its continuation, its foundation, creation and procreation of meanings and interpretations. The reading space is a place of event where text becomes the possibility of event, hence "I desire it as some desire the body of Another, for... text is sensual. The text that opens in the reading space, is our other body that we lust for, over and over again" [37, p. 23]. There exists a certain texture, a certain fabric of reading, in which the consciousness is understood, however paradoxical that may sound [48]. Reading allows for a true touch of reality [39]. Reading configuration assumes the multiplicity of the world come true, because this is an opportunity, which was the beginning and became a reality only after the choice [44, p. 75].

It is possible to discuss absolute text, and hence the fabric of meanings that is open to creation of new meanings, retaining only its shape, style and tone. But it should recognize that the text itself remains something intimate, impossible to control completely, due to the ambiguity created both by the author and the reader who interprets it, giving it new meanings and translating it into his own language.

\section{References}

1. Bakeeva E. V. "Metalingvistika" i ontologiyasobytiya problema svobody // Izvestiya uralskogo federalnogo universiteta. Seriya 3: Obschestvennye nauki. 2012. Vol. 4. Pp. 6-16.

2. Byome Y. Christosophia ili put ko Khristu. SPb.: A-cad. 1994. 224 p.

3. Colbu S. Christian education - between schooling, adult education and lifelong learning // Procedia - Social and Behavioral Sciences. 2014. Vol. 142. Pp. 279-284.

4. Cordoneanu F. Identitary Character and Social Hypostases of Christian-Orthodox Femininity // Procedia - Social and Behavioral Sciences. 2014. Vol. 137. Pp. 205-210.

5. Cristofori I., Bulbulia J., Shaver J. H., Wilson M., Krueger F., Grafman J. Neural correlates of mystical experience // Neuropsychologia. 2016. Vol. 80. Pp. 212-220.

6. Dionysius the Areopagite. Misticheskoye bogosloviye // Misticheskoy bogosloviye. 1994. Kiev: Put k istine. Pp. 5-12.

7. Fortunato A. E. , Langellotto F., Sordino P. Identification and expression of soul/p22HBP genes in zebrafish // Gene Expression Patterns. 2011. Vol. 11. Issues 5-6. Pp. 360-369.

8. Gallate J., Keen S. Intuition // Encyclopedia of Creativity (Second Edition). 2011. Pp. 683-688. 
9. Gaviria P. R. Oneself for another: The construction of intimacy in a world of strangers // Journal of Business Research. 2016. Vol. 69. Is. 1. Pp. 83-93.

10. Goryunov V., Zayats I., Konjkova, T., Murgul V. Architecture, Mysticism and Myths in the Works of Outstanding Architect William Richard Lethaby // Procedia Engineering. 2015. Vol. 117. Pp. 825-831.

11. Hamrah S. Z. Ontological Investigation of the Role of Internet in Religious Education // Procedia - Social and Behavioral Sciences. 2011. Vol. 29. Pp. 1740-1749.

12. Heidegger M. Tezis Kanta o bytii // Vremya I Bytie: Statyi I vystupleniya. Moscow: Respublika. 1993. Pp. 361381.

13. Hills P., Argyle M. Musical and religious experiences and their relationship to happiness // Personality and Individual Differences. 1998. Vol. 25, Is. 1. Pp. 91-102.

14. Hoskins J. Symbolism in Anthropology // International Encyclopedia of the Social \& Behavioral Sciences (Second Edition). 2015. Pp. 860-865.

15. Itzkovich T. V. Kategoriya khronotopa v tekstakh religioznogo stilya (k postanovke voprosa) // Aktualnye problemy filologii I pedagogicheskoy lingvistiki. 2011. Vol. 3. Pp. 112-118.

16. Jacobson-Widding A. Color Classification and Symbolism // International Encyclopedia of the Social \& Behavioral Sciences. 2001. Pp. 2245-2248.

17. Joo Ch. Gw. Marriage and sexuality in terms of Christian theological education // Procedia - Social and Behavioral Sciences. 2015. Vol. 174. Pp. 3940-3947.

18. Joyce R. A. Ritual and Symbolism, Archaeology of // International Encyclopedia of the Social \& Behavioral Sciences (Second Edition). 2015. Pp. 721-726.

19. Katz St.T. Models, modeling and mystical training // Religion. 1982. Vol. 12. Pp. 247-275.

20. Kokosalakis N. Symbolism (Religious) and Icon // International Encyclopedia of the Social \& Behavioral Sciences. 2001. Pp. 15354-15357.

21. Kurabtzev V. Ierusalim Lva Shestova // Vestnik MGU. Seriya 7: filosofiya. 1991. Vol. 5. Pp. 56-75.

22. Kuvakin V. A. Religioznaya filosofiya v Rossii: Nachalo XX veka. 1980. Moscow: Mysl. 309 p.

23. Kuzubova T. S. Metafizicheskiye miry Dostoevskogo i Nitsche. 2001. Yekaterinburg: Ural State University. 309 p.

24. Levin J. Esoteric Healing Traditions: A Conceptual Overview // EXPLORE: The Journal of Science and Healing. 2008. Vol. 4, Issue . Pp. 101-112.

25. Liénard P., Lawson E. Th. Evoked culture, ritualization and religious rituals // Religion. 2008. Vol. 38. Is. 2. Pp. 157-171.

26. Losev A. F. Filosofiya imeni. 1990. Moscow: MSI Press. 269 p.

27. Mann T. Filosophiya Nitzsche v svete nashego opyta // Sobraniye sochineniy. Vol. 10. 1960. Moscow. Pp. 346391.

28. Merezhkovskiy, D. S. Ispanskiye Mistiki. 1997. Tomsk: Vodoley, Izdatelstvo A. Sotnikova. 288 p.

29. Merkur D. Mysticism // International Encyclopedia of the Social \& Behavioral Sciences (Second Edition). 2015. Pp. 168-171.

30. Mohammad A. T. Absence of knowledge, understanding, and perception of time (symphasis with time) as approached by Halqeh mysticism // Procedia - Social and Behavioral Sciences. 2014. Vol. 114. Pp. 71-74.

31. Mohammad A. T. Lack of knowledge, understanding, and perception of journey and destination as approached by Halqeh mysticism // Procedia - Social and Behavioral Sciences. 2014. Vol. 114. Pp. 62-65.

32. Mohammad A. T., Golnaz R. The law of relativity as approached by Halqeh mysticism // Procedia - Social and Behavioral Sciences. 2014. Vol. 114. Pp. 186-190.

33. Muirhead B. Mystical roots // New Scientist. 2009. Vol. 203. Issue 2727. P. 29.

34. Neppe V. M., Close E. R. The Concept of Relative Non-Locality: Theoretical Implications in Consciousness Research // EXPLORE: The Journal of Science and Healing. 2015. Vol. 11. Iss. 2. Pp. 102-108.

35. Nitzsche F. Antikhrist. Proklyatiye Khristianstvu // Sochineniya. Moscow: Ripol Klassik, 1998. Vol. 2. Pp. 637698.

36. Nitzsche F. Chelovecheskoye, slishkom chelovecheskoye // Sochineniya. Moscow: Mysl, 1997. Vol. 1. Pp. 181428.

37. Podoroga V. A. Vyrazhenie i smysl. 1995. M.: Ad Marginem. 427 p.

38. Podoroga V. A. Mir bez soznaniya: Problema telesnosti v filosophii Nitzsche // Problema soznaniya v sovremennoy zapadnoy filosofii. Moscow: Nauka. Pp. 15-31.

39. Salvato L. An interdisciplinary approach to texts as a model for a truthful approach to reality // Procedia - Social and Behavioral Sciences. 2015. Vol. 174. Pp. 2875-2881. 
40. Schlehe J. Anthropology of religion: Disasters and the representations of tradition and modernity // Religion. 2010. Vol. 40. Iss. 2. Pp. 112-120.

41. Scott L. A Mystical Explanation of The Real Historical Jesus // Religion. 2002. Vol. 32. Pp. 273-276.

42. Akhutin A. Primechaniya i kommentarii // Shestov L. Sochineniya: $v 2$ t. M.: Nauka, 1993. Vol. 2. Pp. 405-411.

43. Shestov L. I. Na vesakh Iova (Stranstvovaniya po dusham). Paris: Sovremennye Zapiski, 1929. 375 p.

44. Shutaleva A. V. Artikulirovannoe bytie: k voprosu o topologii apriornykh poznavatel'nykh form sub"ekta $\mathrm{v}$ kontekste filosofskoy antropologii I. Kanta // Epistemy: sbornik nauchnykh statey. Vypusk 8: Problemy sovremennoy ontologii. Ekaterinburg: Azhur, 2013. Pp. 71-75.

45. Shutaleva A. Misticheskiy opyt: filosofskaya dekonstruktsiya // Molodaya mysl' na poroge novogo veka. Ekaterinburg, 2000. Pp. 130-133.

46. Shutaleva A. V. Ontological problem of the studied objects reality in biological worldview // Eastern European Scientific Journal. 2015. No. 1. Pp. 195-198.

47. Shutaleva A. V. Transtsendentsiya kak ontologicheskaya vozmozhnost' soznaniya // Izvestiya Volgogradskogo gosudarstvennogo pedagogicheskogo universiteta. 2009. No. 8. Pp. 38-42.

48. Shutaleva A. V., Putilova E. A. So-bytie chteniya // Istoricheskie, filosofskie, politicheskie i yuridicheskie nauki, kul'turologiya i iskusstvovedenie. Voprosy teorii i praktiki. 2014. No. 12-3(50). Pp. 202-204.

49. Thomas L. E. Late-life effect of early mystical experiences: A cross-cultural comparison // Journal of Aging Studies. 1997. Vol. 11. Iss. 2. Pp. 155-169.

50. Ward C. A transcultural perspective on women and madness: The case of the mystical affliction // Women's Studies International Forum. 1982. Vol. 5. Iss. 5. Pp. 411-418.

51. Yaden, D. B., Eichstaedt, J. C., Schwartz, H. A., Kern, M. L., Le Nguyen, Khoa D.; Wintering N. A.; Hood Jr., Ralph W.; Newberg A. B. The Language of Ineffability: Linguistic Analysis of Mystical Experiences // Psychology of Religion and Spirituality. 2016. Vol. 8. Iss. 3. Pp. 244-252.

52. Yanay-Ventura G., Yanay N. Unhyphenated Jewish religious feminism // Women's Studies International Forum. 2016. Vol. 55. Pp. 18-25. 
DOI: 10.15643/libartrus-2016.5.4

\title{
Конфигурации чтения как конститутивный аспект сознания
}

\author{
(C) А. В. Шуталева ${ }^{1 *}$, Е. А. Путилова² \\ 1 Уральский федеральный университет \\ Россия, 620000 г. Екатеринбург, проспект Ленина, 51. \\ ${ }^{2}$ Нижнетагильский технологический институт (филиал УрФУ) \\ Россия, 622000 г. Нижний Тагил, ул. Красногвардейская, 59. \\ *Email: ashutaleva@yandex.ru
}

\begin{abstract}
Статья посвящена проблеме сознания, одним из основных аспектов которой является способность сознания к конституированию реальности. Конфигурации чтения позволяют представлять проблему сознания в контексте поиска онтологических оснований, что предполагает обращение к его конститутивному аспекту. Со-бытие сознания и реальности рассматривается в качестве текстовой реальности, что позволяет просматривать конфигурации чтения как метафорическое пространство, образованное пересечением и суперпозиции бесконечных текстовых интерпретаций. Обращение к мистической традиции обусловлено пониманием текста как «места» с особой внутренней линии натяжения качественно разнообразного пространства совместного бытия. Интерпретация сознания в аспекте событийности приводит к рассмотрению самостно-экстатической раскрытости субъектности, позволяет представить отношение «я и другой» не в объектной парадигме познания, но как осуществление коммуникации, в которой присутствуют центры инициативы и действия. Конфигурации чтения полагают со-существование нескольких центров притяжения, в котором познание различных аспектов реальности предполагает обращение к традициям катафатического и апофатического способов описания бытия. Одной из основополагающих идей христианской традиции является понимание мира как книги, что обусловливает символический аспект понимании объектов и слов, содержательная сторона которых не исчерпывается обозначением самих себя, но предполагает что-то иное, укромное, что может быть явлено в событии чтения. В мистической традиции осуществляется вопрошание бытия как того, что существует до вещей и является их основой, но не является чем-то неравнодушеным к существованию. Реальность, понимаемая как символический текст, предстает как основа создания и порождения смыслов и интерпретаций, прочтение которого открывает ткань чтения, продолжающих, воспроизводящих и производящих значения текста, обусловленных множественностью смысла, вложенным тем, кто непосредственно писал, но и тем, кто в процессе чтения трактует и переводит на свой язык, вступая в уникальное пространство сосуществования авторского замысла, текста и читающего.
\end{abstract}

Ключевые слова: событие, чтение, сознание, мистический опыт, интерпретация.

Please, cite the article: Shutaleva A. V., Putilova E. A. Configurations of reading as a constitutive aspect of consciousness // Liberal Arts in Russia. 2016. Vol. 5. No. 5. Pp. 466-473. 